\title{
Constraints and Challenges in Livestock Production in Cameroon
}

\author{
Mbu Daniel Tambi*, Forchid Julius Anyah \\ Department of Agricultural Economics, University of Dschang, West Region, Dschang, Cameroon \\ *Corresponding Author \\ Mbu Daniel Tambi \\ Article History \\ Received: 09.07.2019 \\ Accepted: 25.07 .2019 \\ Published: 30.07 .2019
}

\begin{abstract}
This study "Constraints and challenges in Livestock Production in Cameroon", was conducted using Google Earth Maps to mapped out 20 urban and 20 peri-urban points respectively based on settlement in NW region of Cameroon. Data collection was done using a semi-structured questionnaire and analyzed in SPSS version 20.0. Results show that among the challenges/constraints faced by breeders, the most critical were feeding problems, diseases, animal stocks, financial management, access to clean water for the animals and inadequate extension services. These challenges prevent family farms from embracing the transition to agribusiness. The study recommend that breeders should mobilize themselves into Common Initiative Groups, associations as well as seek relevant agricultural insurance policy, this will enable them to manage risk/challenges in Livestock.
\end{abstract}

Keywords: Constraints, Challenges, Livestock, Production, Cameroon

\section{INTRODUCTION}

African agriculture is highly diverse but for the most part, consists of family agriculture. Their contribution to production remains high in most of the countries on the continent; they cannot however be understood simply through their productive function: they also play an important role in food security, employment and revenue, as well as in the management of renewable environmental resources; they thus contribute in an important way to the territorial, social and political balance of a number of countries [1]. Small scale farming is defined or described based on certain characteristics such as farm size, farming system, resource used, quantity and quality of labour, production technology, quantity and quality of output as well as profit generated from farm enterprise. Unlike industrial or large farm enterprise, family farms are generally limited to total land size [2]. A family farm is a farm owned by a family, whose operation is passed down to future generations. The Food and Agriculture Organization of the United Nations defines a "family farm" as one that relies primarily on family members for labour and management. In some usages, "family farm" implies that the farm remains within the ownership of a family over a number of generations. In most African countries, the livestock subsector comprises several or all of the following major small- and large-scale production systems.

The country has 5 agro-ecological zones with different climatic conditions which favour the growth of different and diverse agricultural products. Cameroon is considered as the bread basket of central African Sub Region [3]. It is often referred to as Africa miniature which is full of natural resources and also one of the peaceful nations in Africa. Poverty rates have stagnated at national average of $40 \%$ despite the significant decrease in poverty in Cameroon from $40.2 \%$ in 2001 to $39.9 \%$ in 2007 [4]. According to the World Bank [5] agriculture remains the back bone of Cameroon's economy employing about $70 \%$ of the work force while providing 35 $\%$ of GDP, $30 \%$ of its export and $15 \%$ budgetary resources. Agriculture is the main source of livelihood employing about $86 \%$ of the rural people.

The pace of human population growth coupled with economic and urban development has a considerable impact on livestock production, particularly through the growing demand for animal-derived protein [6]. The global livestock sector is characterized by a dichotomy between developing and developed countries. Total meat production in the developing world tripled between 1980 and 2002, from 45 to 134 million tons [7]. Much of this growth was concentrated in countries that experienced rapid economic growth, particularly in East Asia, and revolved around poultry and pigs. In developed countries, on the other hand production and consumption of livestock products are now growing only slowly or stagnating, although at high levels. Currently,

Copyright @ 2019: This is an open-access article distributed under the terms of the Creative Commons Attribution license which permits unrestricted use, distribution, and reproduction in any medium for non commercial use (NonCommercial, or CC-BY-NC) provided the original author and source are credited. 
livestock is one of the fastest growing agricultural subsectors in developing countries. Its share of agricultural GDP is already 33 per cent and is quickly increasing. This growth is driven by the rapidly increasing demand for livestock products.

The difficulty in assessing the changing disease status in much of the developing world is the lack of data, a critical area where progress needs to be made if disease diagnostics, monitoring and impact assessment are to be made effective and sustainable. Globally, the direct impacts of livestock diseases are decreasing, but the total impacts may actually be increasing, because in a globalized and highly interconnected world, the effects of disease extend far beyond animal sickness and mortality [8]. How can livestock breeding in addition to production and productivity bring about product quality, increase animal welfare, disease resistance and reducing environmental impact? A number of factors that may modify both the production and the consumption of livestock products in the future include competition for land and water, climate change, the role of socio-cultural drivers and ethical concerns. Farmers currently receive only a small fraction of the ultimate value of their output, even if, in theory, risk and rewards should be shared down the chain [9]. To address these issues, our principal objective is to analyze the constraints and challenges in livestock production especially in the transition from family farms to agribusiness in the North West Region of Cameroon.

\section{Risk in Livestock Farming}

Agricultural production in general and livestock farming in particular are risky businesses. Many urban, peri-urban and rural households move out of poverty through agricultural businesses, but agriculture is associated with many types of risk that expose farmers, agribusiness entities and government to potential losses. Wenner and Arias [10] from Inter American Development Bank defined risk as an unavoidable but a manageable element in the agricultural sector. Risk has many meanings. Some dictionaries define "risk" as "the possibility of injury, damage or loss. MINEPIA [11] defines agriculture as an open-topped factory and states that natural risks lead to significant financial losses. These losses, if prevented can boost agricultural output and help to fight poverty. These risks are determined by factors ranging from climate variability and change, frequent natural disasters, uncertainties in yields and prices, weak rural infrastructure, imperfect markets and lack of financial services. Thus, risk is an important aspect of farming business that needs to be well managed.

The sources of risk in livestock farms includes: climate change, pasture management, animal health and disease prevention. As indicated in the paragraphs below; climate change may have substantial effects on the global livestock sector. Livestock production systems will be affected in various ways [12], and changes in productivity are inevitable. Increasing climate variability will undoubtedly increase livestock production risks as well as reduce the ability of farmers to manage these risks. Climate change may have impacts not only on the distribution of disease vectors. Some diseases are associated with water, which may be exacerbated by flooding and complicated by inadequate water access. Droughts may force people and their livestock to move, potentially exposing them to environments with health risks to which they have not previously been exposed. While the direct impacts of climate change on livestock disease over the next two to three decades may be relatively muted [13], there are considerable gaps in knowledge concerning many existing diseases of livestock and their relation to environmental factors. Leeuw et al., [14] point out that production uncertainty is pervasive and serious for households due to the unpredictable nature of climatic conditions. In combination with prevailing poverty the outcome of uncertain events makes households vulnerable to serious hardships and may make a difference between survival and starvation.

With the current increase in crop area, coupled with population growth, less land is available for grazing. Forage forms the main and cheapest feed for ruminants [15]. In Cameroon, almost no work has been done on range management and development except on University farms or research stations, so grazing livestock depend on poor and degraded rangeland that is often of very low nutritional quality. All Cameroon livestock are raised under extensive systems and forage availability is a major problem especially in the dry season. Many farms combine livestock production with the cultivation of crops. Crop residues like straw and stover are used as roughage for livestock, while manure is used for crops. Natural pasture can be an important source of forage if land is not limited. Land restrictions demand intensification through the production of improved forage and better use of crop residues. Livestock animals become less productive on degraded pastures. Cattle take between six and seven years to reach market weight, compared to cattle raised in healthy pasture, which typically take between three and four years. This loss in animal productivity leads to substantially less income and lower rates of capital turnover for producers. Producers are less able to manage risks on degraded pastures, and are more vulnerable to the impact of severe drought or floods [16].

Taking good care of animals does not only mean treating it when it is sick; it means preventing it from becoming ill. Even though treatment may cure the animal, the disease might have affected its body and these effects may last longer than curing the disease itself. Consequently, production losses may continue after the animal has seemingly recovered. Retarded growth in animals and a permanently reduced milk production are examples [14]. It is strongly recommended to call for veterinary assistance for disease prevention as well as when health problems are suspected (veterinarian, veterinary assistant or animal health assistant). Most diseases can be prevented by the same management measures that enhance production; Leeuw et al., [14] proposed the following preventive measures:

- Hygiene, cleaning and disinfecting. Remember disinfection is useless without proper cleaning beforehand.

- Free access to clean and fresh drinking water 
- Providing good and sufficient feed and water at regular times

- Protection against predators, parasites and adverse weather conditions like rain, wind, cold and intensive sunshine.

- A comfortable environment without unrest and stress.

- Avoiding contact with sick animals and game because many diseases are contagious.

Other preventive measures are quarantine, vaccinations and preventive treatments. Quarantine means isolating sick animals and newcomers from the rest of the herd. This helps to avoid the spread of contagious diseases to other animals. Take special care of dung, urine, milk, blood and aborted material as these may transmit the disease to other animals. Assure proper cleaning and disinfecting. Dry and clean floors with bedding are very important. Sick animals need special care. Provide them with shade, protection against wind, clean water and adequate feed. Vaccination against a specific disease helps the animal's body withstand an attack by this disease. Sometimes it will protect the animal during its entire life, but many vaccinations have to be repeated. Unfortunately, vaccinations are not available against all diseases. Preventive treatment can be useful for some seasonal diseases. Examples are treatment of young animals against worms and tick control [14].

To detect health problems in animals, it is necessary to observe them frequently, several times per day. When observing the animal, there is the need to check: (1) Behaviour: does it react normally to its environment and in the group or is it acting strangely? (2) Attitude: does it carry its head, ears, body and tail as usual? Does it walk normally? (3) Condition: is the animal in good condition and is it well muscled, neither too thin nor too fat? (4) Does it eat, drink and ruminate properly? (5) Does it urinate and defecate normally? [14].

The most useful asset a producer can have to help with the management of risk is good information. There are many sources of information available to the producer. The most appropriate place to look for information depends on the type of risk with which the farmer is concerned. The best source of historical production and marketing information is (or should be) the farm records maintained for the farm business. The records may be supplemented and complemented by off farm information, forecasts, and predictions. But there is no substitute for farm record data. Livestock production and cost information generated by farm records reflect the production capabilities of the specific assets controlled by the business. The business management capability is also reflected for both production and marketing aspects of the business. As such, this record information should provide insights into the actual production and price variability experienced by the farm business in the past.

This individual farm information should prove useful in a number of ways. It should provide a good picture of the risk faced by the business in the past. The records should also indicate how successful past risk management efforts have been. Combining these historical results with the producer's risk preferences should point out what, if any, changes in risk management should be made in the future. Is the farm primarily bottom land prone to flooding? Are hills which are susceptible to drought a major problem? Have these situations contributed to greater yield variability than desired? Which animals are the worst? Would a change in cultural practices, or operation timing help to reduce yield variability to a more desirable level? Are animals sold in the farm, local markets or international markets? Has this marketing method (as opposed to a marketing plan) produced greater price variability than desired?

The information provided by farm records should help answer these questions. If past production and marketing decisions have not provided desirable results, the records should show it. Record analysis should also point out things that should be changed to provide better results that are more compatible with the manager's risk preferences. The kind of information not available from on farm sources is that concerning technological, human, legal, and social risk. Farm records should prove useful in providing information about past decisions in these areas. But they will provide little information about what is going to happen in the future in these areas. Off farm sources are required for this information.

\section{LITERATURE REVIEW}

The livestock management process is not only limited by keeping animals in a confined place but has a lot to do with handling and management on a day to day basis. This has to do with meeting their general needs, responding to their immediate needs until there are available for marketing. The livestock management process requires the use of skilled and unskilled labour as well as certain level of experience in livestock farming for success to be guaranteed. The management system of any livestock farm is dependent on the size of farm, type of livestock, and the purpose for which the farm is operating. Proper livestock management is based on the application of best management practices and which include; housing, stocking, feeding, animal health care, breeding and marketing Cattle husbandry national agricultural services Uganda, 2011.

Livestock production is an important component of agricultural activities in developing countries. It is the most important agricultural activity in most of the countries in southern Africa [17]. Livestock are kept for various uses including draught power, milk, meat, eggs and various cultural uses. They compliment cropping activities through the provision of manure for soil fertility maintenance, draught power for cultivation, transport, cash and food [18, 19]. Livestock play an important role in these farming systems, as they offer opportunities for risk coping, farm diversification and intensification, and provide significant livelihood benefits [20]. This brings in another important dimension of integrated crop-livestock farming which is the predominant system of production and subsistence in essentially all communal farming systems. 
Livestock production entails rearing of farm animals e.g cattle, sheep, poultry, goat, pig, rabbits, ducks) by an individual or group of people (Livestock farmers) for profit making. In the production process the animals are usually confined in a particular area (animal farm) and bred through the application of skilled and unskilled management techniques. It should be observed that different livestock species have different ways of managing them thus highlighting good stockman ship as a prerequisite of livestock production. Livestock production can be intensive or extensive. The intensive production is characterized by smaller number of herd sizes (number of animal on the farm), sometimes characterized by limited use of high production technology. The extensive production system with a higher number of population uses advanced production methods. Livestock production is a function of associated cost of production and more importantly the management system in place [21].

Livestock production is one of the main livelihood strategies used by families living in the area, and throughout the larger NWR enabling them to accumulate assets and capital that can be crucial in ensuring the survival of their households in times of crisis. Livestock also provides a major pathway through which poor rural families can improve their incomes and social status [16]. Livestock equally play a vital role in small scale farming systems. Moreover the demand by high income groups in rural areas and cities for animal products provides a viable means for many poor households to earn cash income through sales of eggs, meat and milk. The share of income from animal production including the value of home consumption of animal products usually ranges from 10 to $20 \%$ of rural households [22].

Livestock make an important contribution to extending the quality of diet as well by providing meat, milk, and eggs. Small amount of these high proteins can have very significant impact on human health. Livestock is also a source of both fertilizer and fuel [22]. Livestock have multiple roles in human society. They contribute substantially and directly to food security and to human health. For poor and under-nourished people, particularly children, the addition of modest amounts of livestock products to their diets can have substantial benefits for physical and mental health [23].

Cattle are found throughout Cameroon but the major production areas are in the North West and West region and from the Adamawa Region northward. Herd size is very small in the sub-humid zone because of the high prevalence of trypanosomiasis. Beef production is almost entirely from extensive systems with low inputs. The traditional nomadic system has low productivity due to poor nutrition but has, over the years, met the major demand for beef in Cameroon. For hundreds of years local cattle have adapted to heat, harsh local conditions and management, and developed some resistance to the various environmental stresses. Local breeds are of two types: Bos indicus and Bos Taurus.

Table-1: Data on meat production

\begin{tabular}{|l|l|l|l|l|l|l|l|}
\hline \multirow{2}{*}{ Years } & \multicolumn{7}{l}{ Meat -thousand tonnes } \\
\cline { 2 - 8 } & Cattle & Goats & Sheep & Horse & Pig & Rabbit & Chicken \\
\hline 1995 & 512 & 1303 & 1224 & 1.950 & 400 & 0.090 & 26.5 \\
\hline 1996 & 509 & 1314 & 1242 & 1.950 & 400 & 0.091 & 30.0 \\
\hline 1997 & 521 & 1332 & 1260 & 2.000 & 400 & 0.092 & 33.5 \\
\hline 1998 & 533 & 1350 & 1278 & 2.000 & 480 & 0.092 & 37.5 \\
\hline 1999 & 605 & 1368 & 1314 & 2.050 & 400 & 0.094 & 36.0 \\
\hline 2000 & 647 & 1570 & 1350 & 2.050 & 538 & 0.094 & 26.5 \\
\hline 2001 & 640 & 1570 & 1365 & 2.050 & 540 & 0.096 & 37.5 \\
\hline 2002 & 620 & 1570 & 1365 & 2.100 & 540 & 0.096 & 37.5 \\
\hline 2003 & 620 & 1570 & 1365 & 2.100 & 540 & 0.096 & 37.5 \\
\hline 2004 & 640 & 1570 & 1365 & 2.100 & 540 & 0.096 & 37.5 \\
\hline 2005 & 650 & 1570 & 1365 & 2.100 & 540 & 0.096 & 37.5 \\
\hline 2006 & 650 & 1570 & 1365 & 2.100 & 540 & 0.096 & 37.5 \\
\hline Source: FAOSTAT data 2007. Page 29
\end{tabular}

The Bos indicus are comparatively of higher beef yielding than the taurin cows. There are the Adamawa Zebu (Gudali) and the zebu of the north (Mbororo). Humpless Bos taurus breeds are smaller than zebus, and relatively resistant to trypanosomiasis. They form a very small percentage of Cameroon's cattle. Most cattle rearers in Cameroon are men. Njoya et al., [24] reported that elderly men were involved in cattle rearing in the Northern region. Seventy one percent of farmers were within the age range of 24-50 years while $29 \%$ were above 50 years. In the Menoua Division, cattle rearers come from two principal ethnic groups, the Bororos and the Bamelikes [25], and most them are males (97.03\%) of which $62.38 \%$ are between the ages of $41-80$ years.

\section{METHODOLOGY}

The study area covers two Divisions of NW region of Cameroon (Mezam and Momo) located between latitude $5.55^{\circ}$ North and $10.09^{\circ}$ East. As of 2016 , the projected population was 2.090 .300 million inhabitants with a surface area of $2870 \mathrm{~km}^{2}$ and a population density of 279 people per square kilometer. This area was considered ideal for this study due to its high potential 
production and marketing of livestock. The population growth is fast increasing because of rural exodus. The high search of job opportunities and growth of economic activities has caused the demand for livestock products and food stuffs to increase. There is therefore the need to increase farm productivity to meet the growing population [11].

The study used a cross sectional survey in which data was collected from several points. These points composed of livestock-keeping households. Amongst others, the baseline survey covered aspects on household demographics, production practices, identification of constraints to production and possible solutions, and management practices (feeding, watering, breeding and health provision). The figure below shows how the first point (01) is being located with the used of Google Maps. Image 01_a shows point 01 in all the spotted points, image 01_b shows a satellite view of the point with all the possible roads to arrive at the point and image 01_c shows clearly the settlement around that point and particularly the direction of conducting the survey at that point. The direction is shown by a red arrow.

Table-2: Satellite view of point one (01)

\begin{tabular}{|c|l|l|l|l|}
\hline Point ID & x-Position & y-Position & Direction & Category \\
\hline 01 & 10,143653 & 5,872039 & 253 & peri-urban \\
\hline & E $10^{\circ} 8^{\prime} 37.15^{\prime \prime}$ & N 552'19.34" & N6 \\
\hline \multicolumn{5}{|c|}{ Source: Field survey } \\
\hline
\end{tabular}

\section{Data Presentation}

The target population of the study was livestock farmers. Using the google earth map, 20 urban and 20 peri-urban points were randomly selected based on settlement, followed by a random selection of at most four livestock farmers per point to participate in the study. Points were being located by the use of Google Maps on Smart Phones. The procedure consists of entering coordinates of a point at a time in Google Maps and it immediately shows the direction of the point. Random sampling procedure was used to reduce biasness due large number of livestock farmers available at some points in study area.

The following tools were used for data collection: questionnaires, pencils, eraser, sharpener, exercise book (40 Leaves), a four wheel drive car, rain boots, disinfectant, Smart phone, Global Positioning System and gifts for the farmers (3 Savons per farmer). The primary data from the sampled livestock farmers were collected through formal survey by using a structured questionnaire. The questionnaire was pre-tested before the main survey to check the relevance of questions and to determine whether it was comprehensive enough to collect the required information. The information focus on livestock ownership, priority species kept, purpose for keeping livestock, feeding management, animal health and main problems of livestock keeping. Secondary data were collected from the Divisional Delegation for Livestock, Fisheries and Animal Industries and internet. A total of 160 respondents were obtained and interviewed for this study. Although sample size was limited to 160 it was sufficient enough to allow for statistical analysis. Usually the sample size depends on the size of the population to be sampled although general rule were hard to make without knowledge of specific population The data obtained was summarized, coded, and analyzed by using SPSS 20.0. Descriptive statistics was generated to represent respondents' opinions on various aspects of livestock production and these include frequencies, means, standard deviations, tables, pie chart, bar chart, cumulative frequencies and percentages

\section{EMPIRICAL RESULTS}

\section{Socioeconomic and Demographic Characteristics}

Survey results in Figure-1 indicated that $13.8 \%$ of household heads members were aged between $20-35$ years while $29.4 \%$ were $36-50$ years old, $34.4 \%$ were $51-65$ years and $22.5 \%$ were above 65 years old. The age of household head ranged from 23 years to a maximum of 90 years with the mean age of 53.6313 years old. These findings imply that majority of breeders fall between the age group of 51-65 years who are not energetic enough, as such capable to undertake livestock production activities. Age influences livestock production very much since activities associated with livestock production are less energy demanding compared to other activities like cultivating crops, hence reason why majority of breeder fall between the age 51-65 years. Leeuw et al., [14] urges that in total the accumulation of wealthy is highly dependent on age of an individual, whereby an indirect relationship is experienced. The interviewed livestock farmers in the study areas fall in economically non-productive class, which are dependants.

Furthermore, Figure-1 show that $89.4 \%$ of farmers were married and male headed, $10 \%$ singled and $0.6 \%$ was married. Married respondents are expected to have children who determine the size of household family members anticipated to provide supplementary household labour for Irish potato production. However, when the household has more children than adults it means that the household has too many dependants and hence low economically productive class. Leeuw et al., [14] reported that education is a factor of growth and productivity. The findings indicated that $63.8 \%$ of interviewed farmers had primary education, $11.3 \%$ had secondary education, $8.8 \%$ attended high school, $13.1 \%$ degree holders and $3.1 \%$ attended no formal education. These findings showed a typical characteristic of literacy common for family farm operators in the study area. The implication of this is that, the majority of household heads in the study area have basic education enough for them to seek or receive better livestock production and management technologies available from different sources such as Research Stations, extension agent, publications and mass media. 
Land is a major resource in agricultural production, but keeping of animals does not require much land as compared to the cultivation of crops. Findings indicate that sizes of livestock family farms owned by respondents are small and owned by the individuals. Figure- 1 shows that $88.125 \%$ of farm land is private (owned by the household) and $11.875 \%$ is rented.

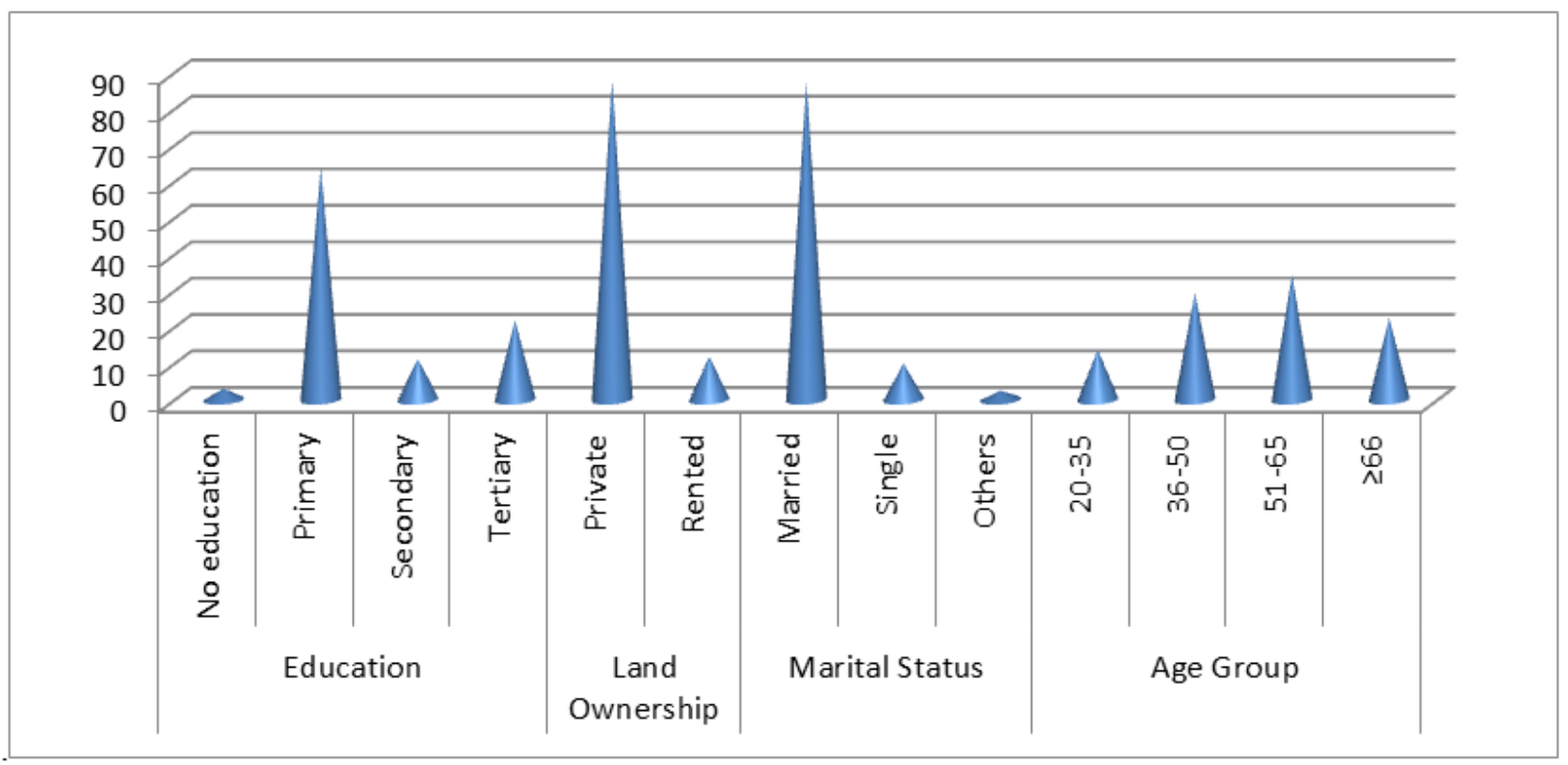

Fig-1: Socioeconomic and Demographic Characteristics of farmers in Livestock Production Source: authors

\section{Constraints to Production}

The table below summarizes how major constraints of livestock production in the study area were captured. Respondents were classified under different constraints based on the difficulties they are facing on their farms. This table permitted us to capture the different constraints faced by family farms as can be seen in Table 3 and 4.

Table-3: Constraints/challenges identified in the study area

\begin{tabular}{|c|c|c|}
\hline No & Constraints/Challenges & Analysis \\
\hline 01 & Animal specie & $\begin{array}{l}\text { - } \text { Do not have good species of animals. } \\
\text { - } \text { - } \text { Dood species are expensive. } \\
\end{array}$ \\
\hline 02 & Feeding & $\begin{array}{l}\text { - } \quad \text { Feed is expensive. } \\
\text { - Quality of feed is low. }\end{array}$ \\
\hline 03 & Animal health (Diseases) & $\begin{array}{l}\text { - Suffer from diseases like: African swine fever, white diarrhea, NCD, foot and } \\
\text { mouth disease }\end{array}$ \\
\hline 04 & $\begin{array}{l}\text { Infrastructure (roads and } \\
\text { market) }\end{array}$ & $\begin{array}{l}\text { - } \quad \text { Difficulties to access the market. } \\
\text { - } \quad \text { Fluctuation in prices of both farm inputs and final products from the farm. }\end{array}$ \\
\hline 05 & Accommodation & $\begin{array}{l}\text { - } \quad \text { Difficulties in accommodating animals. } \\
\text { - } \quad \text { Problem of maintaining good hygiene. }\end{array}$ \\
\hline 06 & Water & $\begin{array}{ll}\text { - } & \text { Access to water is a problem } \\
\text { - } & \text { Available water is of poor quality } \\
\end{array}$ \\
\hline 07 & Extension services & $\begin{array}{l}\text { - Difficulties in seeing a veterinary expert. } \\
\text { - Vaccines are expensive. }\end{array}$ \\
\hline 08 & Farm assets & - $\quad$ Don't have farm assets for example; wheelbarrow, motor bike. \\
\hline 09 & Financial & $\begin{array}{l}\text { - } \quad \text { Capital is a problem. } \\
\text { - No money for investment on more animals }\end{array}$ \\
\hline 10 & Theft & $\begin{array}{l}\text { - } \quad \text { Livestock farmers don't have good security for animals. } \\
\text { - } \quad \text { Rustling is a problem }\end{array}$ \\
\hline 11 & Farmer-grazer conflict & - $\quad$ Breeders and crop producers often in conflict due to animal trespass on farm \\
\hline
\end{tabular}

Source: Author 
Several challenges were highlighted by farmers as constraints to livestock production. Feeding challenges were highest (65\%) among problems faced by farmers in the study area, diseases were the second most popular (40.625\%), financial (38.125\%), followed by infrastructure $(23.75 \%)$, animal species $(16.875 \%)$, farm assets $(14.375 \%)$, access to water $(10.625 \%)$, extension services $(12.5 \%)$, theft (8.1825\%), accommodation (6.875\%), and farmer-grazer conflict( $3.125 \%)$.

From Table-4, $83.125 \%$ of total respondents say animal species is not a constraint. However, 27 households complain that animal species is a constraint. Thus, animal species is not a major constraint in the study area. Cost of feeding animals in the study area is a big challenge since 104 households complain that feeding is a constraint on their farms and only $35 \%$ of total respondents say feeding is not a problem. As such, feeding animals is a major constraint to livestock farmers in the study area. Furthermore, $59.375 \%$ of households said animal disease is a challenge, though 65 respondents complain that animal diseases are a constraint.

Table-4: Livestock production Constraints and Challenges

\begin{tabular}{|l|l|l|l|l|l|}
\hline Variables & TR & C & NC & CD ( NC-C $)$ & PNC \\
\hline Animal specie & 160 & $0.16875(27)$ & $0.83125(133)$ & $0.6625(106)$ & 83.125 \\
\hline Feeding & 160 & $0.65(104)$ & $0.35(56)$ & $0.3(-48)$ & 35 \\
\hline Animal health (Diseases) & 160 & $0.40625(65)$ & $0.5937(95)$ & $0.1875(30)$ & 59.375 \\
\hline Infrastructure (road, market..) & 160 & $0.2375(38)$ & $0.7625(122)$ & $0.525(84)$ & 76.25 \\
\hline Accommodation & 160 & $0.06875(11)$ & $0.9312(149)$ & $0.8625(138)$ & 93.125 \\
\hline Water & 160 & $0.10625(17)$ & $0.89375(143)$ & $0.7875(126)$ & 89.375 \\
\hline Extension services & 160 & $0.125(20)$ & $0.875(140)$ & $00.75(120)$ & 87.5 \\
\hline Farm assets & 160 & $0.14375(23)$ & $0.8562(137)$ & $0.7125(114)$ & 85.625 \\
\hline Financial & 160 & $0.38125(61)$ & $0.61875(99)$ & $0.2375(38)$ & 61.875 \\
\hline Theft & 160 & $0.08125(13)$ & $0.9187(147)$ & $0.8375(134)$ & 91.875 \\
\hline Farmer-grazer conflict & 160 & $0.03125(5)$ & $0.96875(155)$ & $0.9375(150)$ & 96.875 \\
\hline
\end{tabular}

Source: Field survey. NB: TR= Total respondent, $C=$ constraint, $N C=$ non constraint, $C D=$ constraint difference, $P N C=$ percentage non constraint.

Since all the values in the column of $C D$ are all positive except that of feeding, it means that animal species, diseases, infrastructure, accommodation, water, extension services, farm assets, financial difficulties, theft and farmer-grazer conflicts are not major constraints to livestock owners in the study area. The negative value of feeding in the $C D$ column means that feeding is a major problem to livestock farmers. These findings permitted us to answer our main research question $\left(\mathrm{q}_{3}\right)$ and to come to a conclusion with our research hypothesis. We rejected $\mathrm{H}_{1}$ and concluded that; Livestock family farms in the North West region of Cameroon do not have many production and management constraints nor opportunities that affect their productivity and sustainability.

\section{CONCLUSION}

This study was conducted in Mezam and Momo divisions of North West Region of Cameroon. The main objective was to identify and catalogue constraints and challenges for livestock production. The study area comprised Bamenda and its peripheries made up of Urban and Periurban points respectively. Using Google Earth Maps (GEM), twenty (20) urban and twenty (20) periurban points were randomly selected based on settlement, followed by a random selection of at most four livestock farmers per point to participate in the study.

A sample size of 160 respondents was used in this work. Data collection entailed using a semi-structured questionnaire. Information collected included: house-hold demographics, production practices, identification of constraints to production and possible solutions, and management practices (feeding, watering, breeding and health provision). The data were analysed using the Statistical Package for the Social Sciences (SPSS) version 20. Farmers kept a variety of livestock species of which most were pigs. Pigs were the most common species kept by households. Although poultry were the second most common species kept, they were more important than all other species in the livelihoods of farmers due to their various roles. Free range of indigenous fowls and easy accommodation of hundred of table birds. Among challenges faced by farmers the most critical were feeding problems, diseases, animal species, and financial difficulties, access to water and quality and inadequate extension service.

\section{REFERENCES}

1. Mercoiret, R. Pesche, D., \& Bosc, P. M. (2006). Rural producer organizations (RPOs) for pro-poor Sustainable development. Report of Paris Workshop, 30-31 October.

2. Ellis, F. (2012). Small farms, livelihood diversification, and rural-urban transitions: Strategic issues in sub-Saharan Africa. Overseas Development Group (ODG) University of East Anglia Norwich NR4 7TJ, UK.

3. Food and Agriculture Organization (FAO). (2012). Promoting the growth and development of smallholder seed enterprises for food security crops: Case studies from Brazil, Côte d'Ivoire and India. Rome, Italy: FAO.

4. World Bank 2010. Minding the stock: bringing public policy to bear on livestock sector development. Washington, DC. Report no. 44010-GLB. 
5. World Bank. (2011). Intensification of Livestock Production systems in the North West Region of Cameroon. A South to South Collaboration for Technology Transfer. The Tugi Silvopastoral Project. Washington, D.C: Author.

6. Delgado, C. (2005). Rising demand for meat and milk in developing countries: implications for grasslands-based livestock production. In Grassland: a global resource.

7. World Bank. (2009). Managing agricultural risk, vulnerability and disaster. In Agriculture Investment Sourcebook Module 10. Available at World Bank website.

8. Perry, B., \& Sones, K. (2009). Global livestock disease dynamics over the last quarter century: drivers, impacts and implications. Rome, Italy: FAO. (Background paper for the SOFA 2009).

9. Rota, A., \& Sperandini, S. (2010). Gender and Livestock. Livestock Thematic Papers: Tools for Project Design. Rome.

10. Wenner, N., \& Arias, D. (2003). Agricultural insurance in Latin America: Where arewe? Presented at the International Conference: Paving the Way Forward for Rural Finance, 2-4 June, Washington, DC, USA.

11. Ministère de l'Elevage, des Pêches et des Industries Animales (MINEPIA). (2002). La stratégie sectorielle de l'élevage, des pêches et des industries animales. Cameroun. 93.

12. Thornton, P. (2009). Mapping Poverty and Livestock. Report to the Department for International Development. International Livestock Research Institute, Nairobi. Three endemic foci in South-Eastern Uganda. Ann Trop Med Parasitol.

13. King, D. A., Peckham, C., Waage, J. K., Brownlie, J., \& Woolhouse, M. E. (2006). Infectious diseases: preparing for the future. Science, 313, 1392-1393.

14. De Leeuw, P. N., McDermott, J. J., \& Lebbie, S. H. B. (1995). Monitoring of livestock health and production in sub-Saharan Africa. Preventive Veterinary Medicine, 25(2), 195-212.

15. Pamo, E. T., Fonteh, F. A., Tendonkeng, F., Kana, J. R., Boukila, B., Djaga, P. J., \& Fomewang II, G. (2006). Influence of supplementary feeding with multipurpose leguminous tree leaves on kid growth and milk production in the West African dwarf goat. Small Ruminant Research, 63(1-2), 142-149.

16. Nji, A., \& Fonteh, M. F. (2002). Water harvesting: Its potential in the greening and poverty reduction of Northern Cameroon. Journal of the Cameroon Academy of Sciences, 2(1), 33-48.

17. Mamabolo, M. J., \& Webb, E. C. (2005). Goat Production Survey-Fundamental Aspects to Model Goat Production Systems in Southern Africa-Case Study. Agricultural Commission.

18. Powell, A., Piccoli, G., \& Ives, B. (2004). Virtual teams: a review of current literature and directions for future research. $A C M$ SIGMIS Database: the DATABASE for Advances in Information Systems, 35(1), 6-36.

19. Peden, D., Tadesse, G., \& Misra, A. K. (2005). Water and livestock for human development. In Water for food, water for life: a comprehensive assessment of water management in agriculture. Earthscan, London, and IWMI, Colombo.

20. Bossio, D., Erkossa, T., Dile, Y., McCartney, M., Killiches, F., \& Hoff, H. (2012). Water implications of foreign direct investment in Ethiopia's agricultural sector. Water Alternatives, 5(2).

21. Waiswa, C., Olaho-Mukani, W., \& Katunguka-Rwakishaya, E. (2003). Domestic animals as reservoirs for sleeping sickness in three endemic foci in south-eastern Uganda. Annals of Tropical Medicine \& Parasitology, 97(2), 149-155.

22. Zeller, M., \& Sharma, M. (2000). Rural finance and poverty alleviation. Food Policy Report. International Food Policy Research Institute (IFPRI): Washington, DC.

23. Neumann, C. (2003). Animal source foods improve dietary quality, micronutrient status, growth and cognitive function in Kenyan school children: background, study design and baseline findings. J. Nutr. 133, 3941S-3949S.

24. Njoya, A., Bouchel, D., \& Ngo, T. (1997). Systèmes D'élevage et productivité des bovins en milieu paysan. ASNC: vers un développement solidaire des savanes d'Afrique Central. Montpelier, France, CIRAD-C -528.

25. Yendji, B. (2000). Caractéristiques socio-économiques et techniques de l'élevage bovin sur les hautes terre de l'OuestCameroun: Cas du département de la Ménoua. Mémoire d'ingénieur agronome, Université de Dschang, 85. 